\title{
Succession rates and patterns twelve years after land use abandonment in the estuary of the River Aliakmon, N. Greece
}

\author{
Fotios Xystrakis ${ }^{1 *}$, Kostantinos TheOdoropoulos ${ }^{2}$, Eleni EleFtheriadou ${ }^{2}$, \\ Dimitrios A. SAMARAS ${ }^{3}$, Christos Damianidis ${ }^{2}$, TheOdoros PAPAdOPOUlos ${ }^{2}$ \\ ${ }^{1}$ Department of Environmental and Natural Resources Management, University of \\ Patras, G. Seferi 2, GR-30100 Agrinio, Greece \\ ${ }^{2}$ Faculty of Forestry and Natural Environment, Aristotle University of Thessaloniki, \\ GR-54124 Thessaloniki, Greece. \\ ${ }^{3}$ Gr. Xenopoulou 44, GR-16346 Athens, Greece.
}

\begin{abstract}
Vegetation succession is a key element for research studying biodiversity losses, effects of climatic change on ecosystems, invasive species and restoration of ecosystems in which human activities have shifted their natural or semi-natural vegetation. Surrogate variables like Pignatti's bioindicator values or dissimilarity indices can provide further insights regarding succession trajectories aggregating the combined effects of changes in the cover/abundance of taxa. The land-use abandonment in an area in the estuary of the River Aliakmon, N. Greece, provides an opportunity to study medium-term rates and patterns during the first twelve years of vegetation succession. Cluster and time-series analyses of turnover rates, Sørensen's dissimilarity index and Pignatti's bioindicator values revealed clear differences in succession patterns and rates among permanent plots. Succession rates and patterns in the study area were found to be dominated by two ecological factors. On the one hand, availability of fresh water, assumed by the proximity to the river, allows the fast growing Populus alba to develop a forest canopy that radically alters the shading environment which, in its turn, controls succession trajectories. Increased soil salinity on the other hand, allows salt-tolerant taxa to be quickly established, and defines the species inventory on these sites as early as the first years of succession.
\end{abstract}

Key words: Forest canopy, halophytic vegetation, Pignatti's bioindicator, soil salinity, succession, riverine forest, time-series

\section{Introduction}

Vegetation succession is a key element for research studying biodiversity losses, effects of climatic change on ecosystems, invasive species and restoration of ecosystems in which

\footnotetext{
* Corresponding author, e-mail: fotios.xystrakis@gmail.com

Copyright $^{\circledR} 2014$ by Acta Botanica Croatica, the Faculty of Science, University of Zagreb. All rights reserved.
} 
human activities have shifted the natural or semi-natural vegetation (PRACH et al. 2001, PRACH and WALKER 2011). Ecological restoration can, in addition to its main components of planning, implementation and evaluation, be regarded as the implementation of succession concepts (ZEDLER 2005, HoBBS et al. 2007) or as a form of manipulated succession (MATTHEwS and ENDRESS 2010). To exemplify, information concerning long-term succession assists rational planning that reduces the possibility of undesirable results; or else allows for the definition of a framework of possible trajectories within which restoration can occur and defines the time frames within which restoration should be evaluated and further intervention is needed (HoBBS et al. 2007, ŘEHOUNKOVÁ and PRACH 2008). This linkage between restoration ecology and succession implies that as much input as possible concerning ecological processes and functioning should be available (PRACH et al. 2001). Management practises can be based on the knowledge of vegetation dynamics including succession rates and patterns and estimated final succession stages (BONET 2004). Knowledge of succession stages can also support conservation practices for endangered taxa of fauna and flora (LAURENCE et al. 2010, TROPEK et al. 2010). Restoration practices could be evaluated on the basis of the similarity of the restored ecosystem to a reference biocoenosis, species composition and abundance, among other criteria.

Succession can be studied by means of chronosequences or permanent research plots, combined, or not, with experimental manipulations and meta-analyses (AUSTIN 1977, PRACH and WALKER 2011). Direct observations over time should be preferred over chronosequence methods because the latter assume similar environmental conditions for different ages and this is not always valid (FASTIE 1995). Nevertheless, chronosequences and permanent plots can be complementary and simultaneously used to test different hypotheses (BAKKER et al. 1996). Widely adopted approaches for succession analysis include the identification of cluster transitions; direction in terms of species composition; individual species analysis at the level of presence/absence or abundance; and changes in plant traits or syntaxonomic elements (BAKKER et al. 1996). Various applications of permanent plots that are used to study the internal causes and mechanisms of succession can be found in BAKKER et al. (1996). To measure the pace of succession two approaches are usually adopted: (1) to measure the rate at which species composition changes from early- to late-successional stages, and (2) to measure the deceleration of species gain and turnover rates over time (MATTHEWS and ENDRESS 2010).

Successional trends and trajectories are often more apparent when plot data are aggregated to the level of functional groups, plant strategy types, or indicator values (BAKKER et al. 1996, KAhMEn and Poschlod 2004, MATthews and EndRess 2010, Prévosto et al. 2011), as was also shown for the study area (XYSTRAKIS et al. 2011). Ellenberg's indicator values, or similar approaches, can be used as surrogates for changes in environmental factors in plant communities (DZWONKo 2001). Despite the criticisms and the problems that often occur with their use (SMART and SCOTT 2004), under certain circumstances, they can adequately replace measurements of environmental variables (DIEKMANN 2003, EWALD 2003).

Estuaries and wetlands in general reflect a history of long term human influence. Fertile soils and availability of irrigation are among the main factors supporting intensified agriculture which in its turn, stresses wetland functions (GERAKIS and KALBURTJI 1998). A considerable area of wetland ecosystems has been lost over the last decades in the northern Mediterranean region with the major threat consisting of the alteration in their hydrological 
status to provide for the needs of farming (BRINSON and MALVÁREZ 2002) as well as of direct loss of wetland area (ZALIDIS et al. 1997). The latter specifically affected more than $50 \%$ of Greek marshes and estuaries (ZALIDIS et al. 1997). Given the ecological importance of wetlands, alongside their over-exploitation, especially in Greece (ZALIDIS et al. 1997, GERAKIS and KALBURTJ 1998, SMARDON 2009), it is not surprising that the development of protection and restoration strategies accompanied by appropriate legislation gained importance at both international and national levels (SMARDON 2009). The tight relation between restoration and vegetation succession explains why the latter is widely discussed in the relevant literature (Roozen and Westhoff 1985, Rossell et al. 2009, Matthews and Endress 2010). Nevertheless, in Greece there is still a considerable lack of experience regarding the successional pattern of wetland vegetation and within this concept, our objective is to analyze the vegetation succession after 12 years of land use abandonment (agriculture and grazing) using a case study approach in the estuaries of the River Aliakmon, N. Greece. We try to provide insights regarding changes in succession rates and the different succession trajectories that are observed in the study area.

\section{Study area}

The study area, 'Stergiou Ecopark' (Fig. 1), an area of $c a 3.54 \mathrm{~km}^{2}$, is part of a larger complex of wetlands that are listed under the Ramsar convention and are included in the NATURA 2000 network of directive 92/43/EEC (site name: Delta Axiou-Loudia-Aliakmona-Evryteri periochi-Axioupoli. GR1220002), indicating the high conservation significance of the area. The land use in the ecopark, until the year 1999, was mainly rice cultivation and partly cattle grazing in some uncultivated, halophytic communities. In 1999 'Stergiou ecopark' was included in the Greek Ministry of Agriculture project 'Long-term pause of cultivation of agricultural land' based on Council Regulation (EEC) 2078/1992 and land use (agriculture and grazing) was abandoned.

Soils are mainly alluvial deposits with high salinity levels over most of the ecopark's area. The climate of the area, based on Köppen's classification, is characterized as 'Mediterranean with mild winters and warm, dry summers (Csa)' (KöPPEN 1931). According to the natural potential vegetation map of Europe (BOHN et al. 2000), the natural vegetation of the wider study area is characterized by a mosaic of Aegean halophytic vegetation (Salicornia europaea, Sarcocornia perennis, Halocnemum strobilaceum, Juncus maritimus, J. subulatus, Schoenoplectus litoralis, Aeluropus littoralis) (code P28) and patches of East Mediterranean brackish water tamarisk scrub (Tamarix hampeana) with Juncus maritimus and J. heldreichianus (code U39).

The actual vegetation of the wider study area consists of patches of Populus alba and Alnus glutinosa canopy forests in the vicinity of the Aliakmon, reed beds (Phragmites australis) along the irrigation canals, tamarisk-dominated communities (T. hampeana) and where the soil salinity is high, made apparent from the existence of salt crystals on the surface of the soil, communities of halophytic vegetation dominate. The latter include, for example, the taxa Sarcocornia perennis, Halimione portulacoides, Salicornia europaea, Hordeum marinum and Puccinellia distans subsp. distans. 


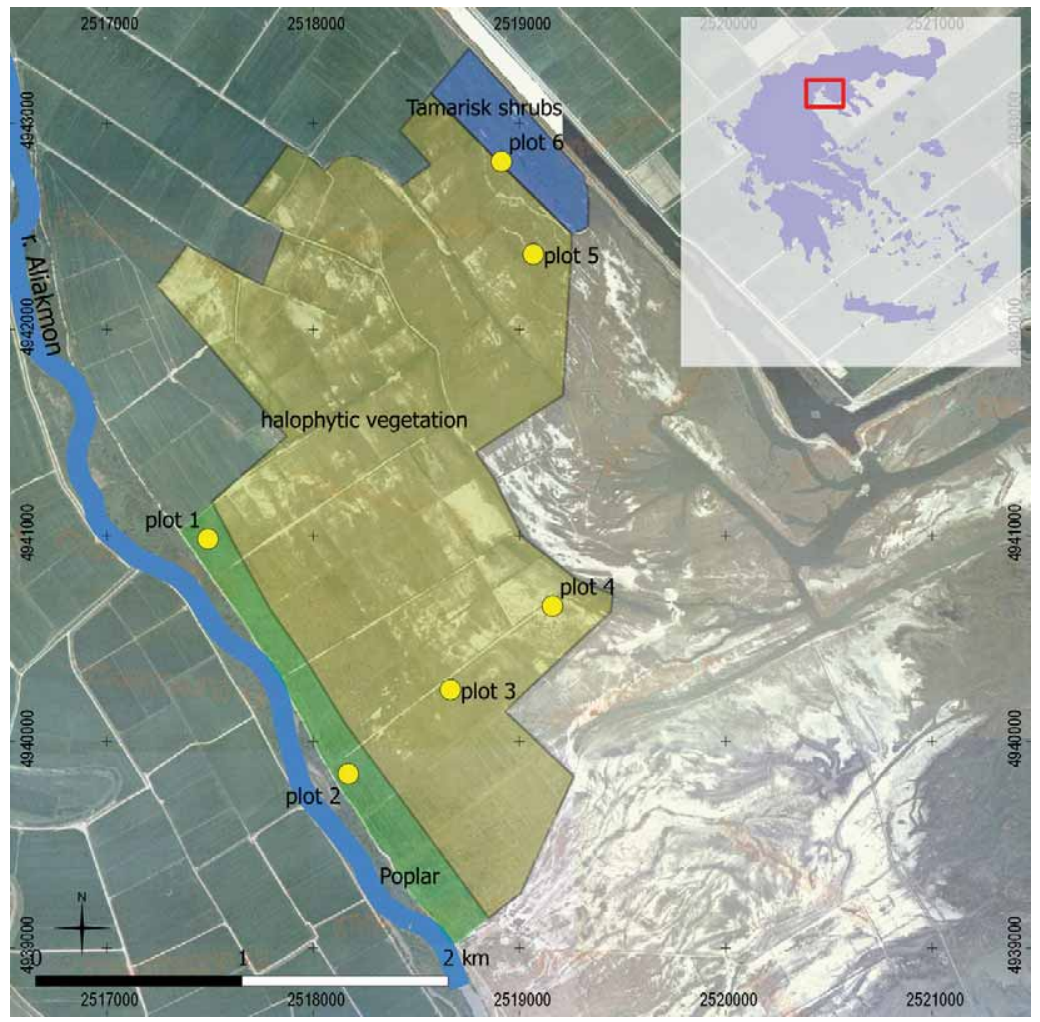

Fig. 1. The 'Stergiou ecopark'. Distribution of plots is annotated. Tamarisk scrublands are located at the north-east part of the ecopark, while riverine forest (mainly poplars) is distributed in the vicinity of river Aliakmon. Halophytic communities dominate the study area, yet a large part near the centre of the ecopark is periodically flooded, restricting further sampling. Background map: S.A. Coordinate reference system: GGRS'87 EPSG code: 2100) (Copyright (C) 2012, Ktimatologio S.A.).

\section{Materials and methods}

Six permanent plots of $100 \mathrm{~m}^{2}$ were established during 2000 in the dominant vegetation types occurring in the area (Fig. 1). More specifically, two were placed at rather short distance from the Aliakmon, where seedlings of Populus alba and Salix spp. were already present from the first year (plots 1,2), three in halophilous vegetation types that among others included the taxa Salicornia europaea, Salsola soda, Suaeda maritima, Puccinellia distans, Hordeum marinum at different cover values (plots 3, 4, 5), and finally one in Tamarix hampeana-dominated scrubland (plot 6). Plots 1 to 4 were established in ex rice cultivation areas and plot 5 in rangeland. Vegetation was sampled based on Braun-Blanquet's method (BRAUN-BLANQUET 1964). All vascular plant species occurring were identified and their cover/abundance was estimated by means of the 7-class Braun-Blanquet ordinal scale, after having been classified in three different layers: tree layer (height $>5 \mathrm{~m}$ ), shrub layer $(0.5 \mathrm{~m}<$ height $<5 \mathrm{~m})$ and ground layer (height $<0.5 \mathrm{~m})$. Additional environmental variables included the visual estimation of tree height and the total cover of each 
vegetation layer. Vegetation data can be found in the ANNEX in XYSTRAKIS et al. (2011). Specimen identification was made by means of Tutin et al $(1968,1972,1976,1980)$, Tutin et al. (1993) and StRID and TAN $(1997,2002)$. Nomenclature follows (in order) EuRO+MED (2006-2010), STRID and TAN (1997, 2002), JAHN and SCHÖNFELDER (1995), GREUTER et al. (1984, 1986, 1989), Tutin et al. (1968, 1972, 1976, 1980) and TuTIN et al. (1993).

To study succession, various turnover rates and the changes on taxa indicator values were analysed, using the following methods:

Cluster analysis was performed in order to assess the similarity in vegetation composition through the succession years as well as among plots. Relative Euclidean distance and Ward's linkage method were used in the matrix in such a way that species abundances were $\log$ transformed and species appearing in two plots or less were excluded. We decided though to preserve taxa occurring at different layers (ground, shrub, tree) as distinct taxa, since vegetation layering provides insights in succession processes. The vegetation matrix consisted of 72 plots and 128 species. The analysis was performed in PC-ORD (MCCUNE and MEFFORD 2006).

\section{Turnover rate}

Short-term turnover rates were estimated adopting the methods from MatTHEws and ENDRESS (2010). Therefore for each plot, taxa abundances were transformed into presence/ absence and the measures for proportional loss $\left(\mathrm{L}_{\mathrm{p}}\right)$, proportional gain $\left(\mathrm{G}_{\mathrm{p}}\right)$ and proportional turnover $\left(\mathrm{T}_{\mathrm{p}}\right)$ were estimated using the following equations:

$$
\begin{gathered}
G_{p}=\frac{G}{\frac{1}{2}\left(S_{t}+S_{t+1}\right)} \\
L_{p}=\frac{L}{\frac{1}{2}\left(S_{t}+S_{t+1}\right)} \\
T_{p}=\frac{G+L}{\left(S_{t}+S_{t+1}\right)}
\end{gathered}
$$

With: $\mathrm{S}_{\mathrm{t}}=$ Number of taxa in year $t$

$\mathrm{G}=$ Number of taxa in year $t+1$, not present in year $t$

$\mathrm{L}=$ Number of taxa in year $t$, not present in year $t+1$

Since these turnover rates, based on presence/absence data for taxa, do not include changes on species cover values, the succession rates were also displayed as the year to year change in the vegetation composition by means of the calculation of the dissimilarity (Sørensen distance measure) among all the plots of each year and the earliest year plots (Du et al. 2007). Dissimilarity values were also aggregated to the level of the defined groups that were derived from the cluster analysis. To estimate the Sørensen distance measure, taxa abundance/cover values were transformed according to the transformations proposed by MAAREL, VAN DER (2007). It has to be pointed that the form of Sørensen's distance measure, as implemented in PCord, uses taxa cover/abundance values. Here we adopt the nomenclature followed in PCord (MCCUNE and MEFFORD 2006). 
Alongside the study of the changes on the basis of cover/abundance of plant species in each plot, succession was also studied on the basis of the changes in weighted-average of Pignatti's bioindicator values for each plot, each succession year (PIGNATTI 2005). This approach has been questioned with respect to its ability to provide information independent of the floristic census results, since cover/abundance values of plant species and bioindicator values have the problem of circular argumentation. Nevertheless, it is the only method able partially to fill the gaps occasioned by the lack of measured ecological data. Salinity values were excluded from the analysis because they were available for only a limited number of taxa.

Inter-annual differences in dissimilarity index (Sørensen's distance) as well as inter-annual change in the Pignatti bioindicator values can be considered and treated as univariate time series. Therefore, the nonparametric Mann-Kendall trend test (HIPEL and MCLEOD 1994) was performed in order to investigate possible trends along the succession years. The analysis was performed by means of the 'Kendall' package in R ( $\mathrm{R}$ DEVELOPMENT CORE TEAM 2011). Moreover, since it is argued that early years of succession reflect higher turnover rates than later phases (ODLAND and DEL MORAL 2001), for the time series reflecting trends as shown from the Mann-Kendall trend test, we tested whether the time-series were trend-stationary, allowing for a structure break in both their level and slope or were unit root processes. The analysis was performed by means of the Zivot and Andrews unit root test implemented in the 'urca' package in R (R DeVElopment CoRE TEAm 2011). The analyses were performed for every plot as well as for the averaged values of the defined groups from the cluster analysis (plots 1,2,3,4,5) that showed similar responses in terms of succession but only the latter presented in this paper.

\section{Results}

Cluster analysis showed that plots can be grouped in three distinct groups (Fig. 2): Group a, which includes plots 1 and 2, group b which includes plots 3, 4 and 5 and finally, group $\mathrm{c}$ which only includes plot 6 . It is interesting to observe that group b could be further divided in two distinct clusters, the first containing plot 3 (all years of succession) and plot 4 (three first succession years) and the second containing plot 5 (all years of succession) and plot 4 (latest nine succession years). This indicates that plot 4 resembled plot 3 during the first years of succession but then, its succession trajectory resembled that of plot 5. Moreover, it has to be pointed out that these results allow us to consider plots 3, 4 and 5 on a common basis, regardless of the differences in land use before land abandonment. Finally, it has to be mentioned that since plot 6 shows distinct patterns of succession and floristic composition from the rest of the plots (the vegetation consists of dense tamarisk scrubland, and it was actually never managed as rice field) it was decided it would be excluded from further analyses.

Based on the species turnover rates, and the analysis of species gain and loss for each plot (Fig. 3) it can be observed that changes on species occurrence may not result in changes in overall turnover rates. During the first years of succession, there is a generally great loss of species and only a few new species are introduced in the plots, while in the third year of succession, the turnover rates are mostly based on the introduction of new species in the floristic inventory of the plots. Nevertheless, there is fluctuation between annual gain and loss of species, leading to respective fluctuations in annual turnover rates. 


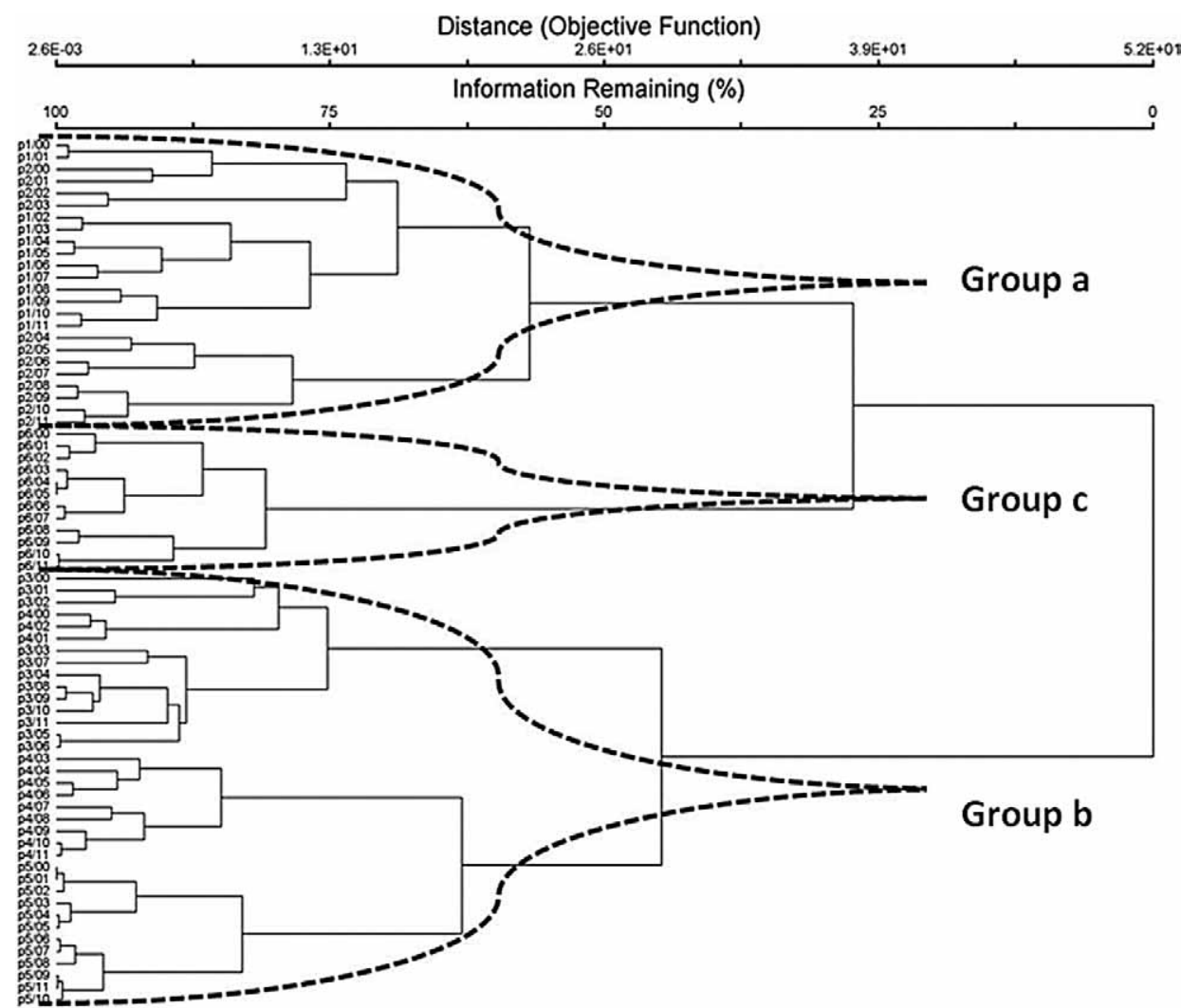

Fig. 2. Cluster dendrogram of plots. Three main groups can be identified, distinguishing plots during succession process: Group a, including plots 1 and 2 (poplar stands), group b, including plots 3,4 and 5 (halophytic communities) and group 6, only including plot 6 (dense tamarisk shrubland).

The trend of the Sørensen dissimilarity index was significant at the 0.05 level (tau $=$ 0.848 and tau $=0.788$ for groups a and b respectively) (Fig. 4). Structural change tests identified possible breaks in both level and slope in the years 2006 and 2008 for plots of group a and $\mathrm{b}$ respectively. It is worth noting that the intervals where the possible break may occur $(\mathrm{t}$ statistic in Zivot and Andrews test significant at the 0.05 level) for group b show a great amplitude, expanding from year 2004 to 2011.

Regarding plots of group a (plots 1 and 2), there is a clear trend in some of the weighted averaged Pignatti bioindicator values during the succession process (Fig. 5). We present only the outputs for Pignatti's values of light, humidity and nutrients as they are the more striking examples. Only changes in temperature, continentality and soil reaction values are discussed in the text. The Mann-Kendall trend test identified a significant linear trend at $95 \%$ confidence for light $(\mathrm{tau}=-0.879)$ nutrients $(\mathrm{tau}=-0.646)$ and humidity $(\operatorname{tau}=$ -0.473 ). Structural change tests revealed structural changes for humidity and nutrient (Fig. 5), Pignatti's bioindicator values for light reflect a clear decreasing trend without any structural breaks, indicating that during the first 12 years of succession they were constantly 


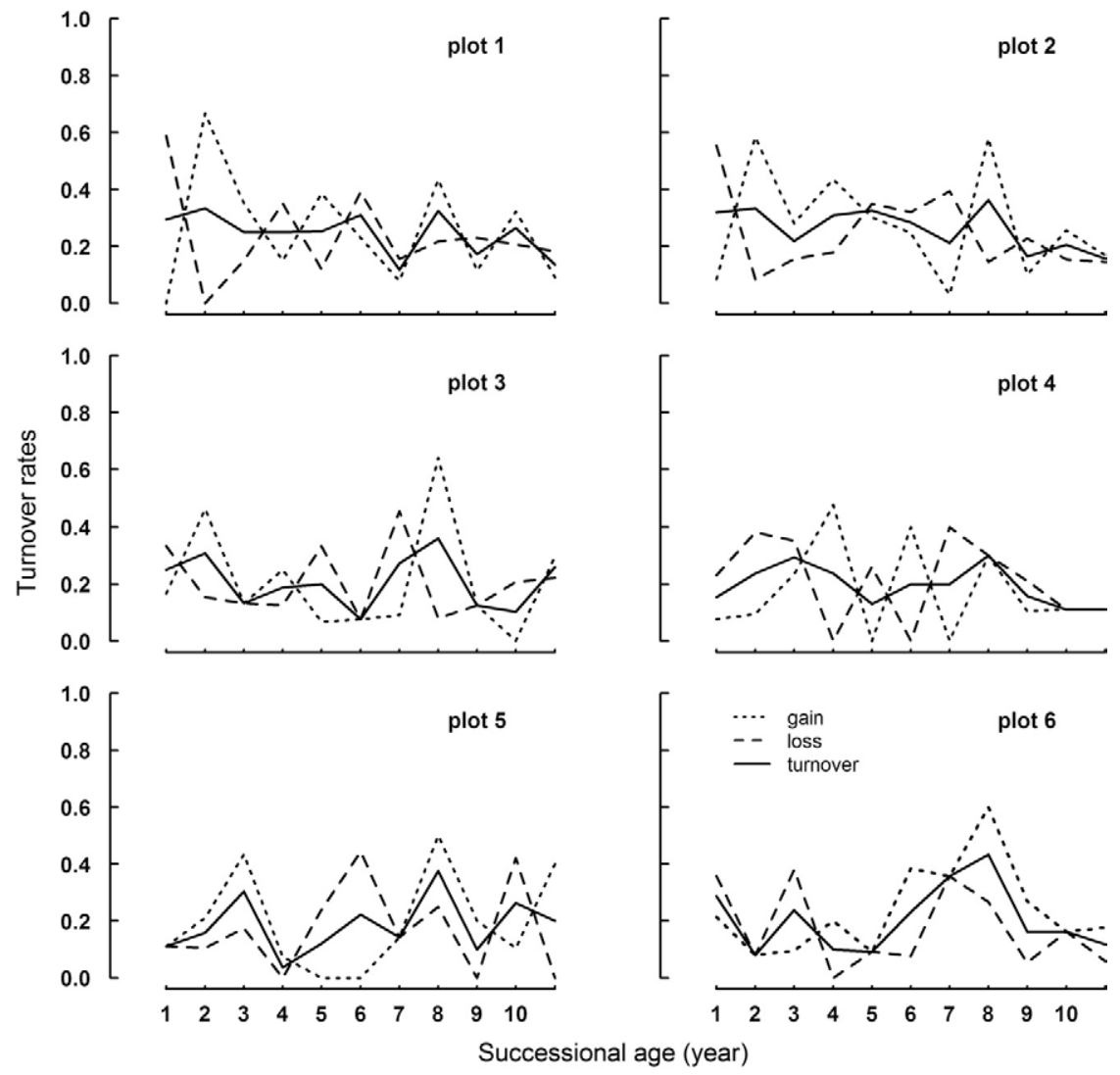

Fig. 3. Gain and loss of taxa and turnover rates during succession
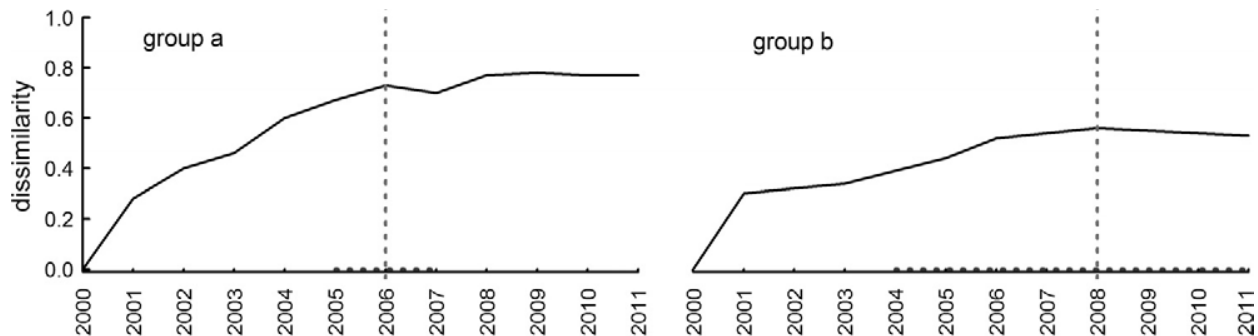
year

Fig. 4. Sørensen's dissimilarity index for plots of group a (left) and of group b (right). All values refer to differences from the first year (2000). Vertical lines indicate the year during which a possible shift in both level and slope occurs. Horizontal lines around the year of possible shift indicate the period when $\mathrm{t}$ statistic of Zivot and Andrews test falls below the 0.05 level

decreasing and that the flattening of the curve after the year 2009 is not yet sufficient for it to be identified as possible break in level and slope. The lack of a clear trend in Pignatti's temperature, reaction and continentality values indicates that succession and changes in 

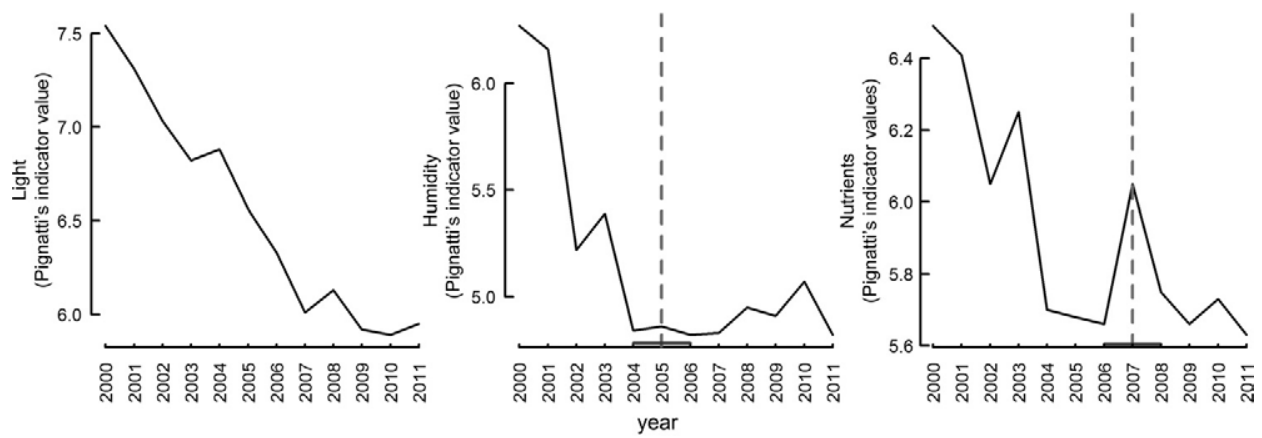

Fig. 5. Pignatti's bioindicator values (y axis) of aggregated plots of group a during succession (x axis). Annual fluctuations can be observed, yet trends are also apparent. Vertical lines indicate the year during which a possible shift in both level and slope occurs. Horizontal lines around the year of possible shift indicate the period when t statistic of Zivot and Andrews test falls below the 0.05 level

species cover/abundance values only slightly influenced these parameters, or that there are intense interannual fluctuations, not allowing for the distinction of a clear trend.

Similar outputs were obtained for the aggregated values of plot 3, 4 and 5 (Fig. 6), where only the outputs for Pignatti's values of light, humidity and nutrient are presented. Changes in temperature, continentality and soil reaction values are considered. Some weighed averaged Pignatti's bioindicator values show clear indications of linear trends, while other rather reflect inter-annual fluctuations. The Mann-Kendall trend test identified significant trends at $95 \%$ confidence level for light $(\mathrm{tau}=0.545)$; humidity $(\mathrm{tau}=-0.626)$; soil reaction $(\mathrm{tau}=$ -554 ) and continentality ( $\mathrm{tau}=-626$ ), while temperature and nutrient values were not found to have significant linear trends. Structural change tests revealed significant changes in level and slope only for Pignatti's light values. Values of humidity and continentality, although showing clear decreasing trends, do not show patterns of structural breaks in slope and level, while values of soil reaction probably have a break only in level.
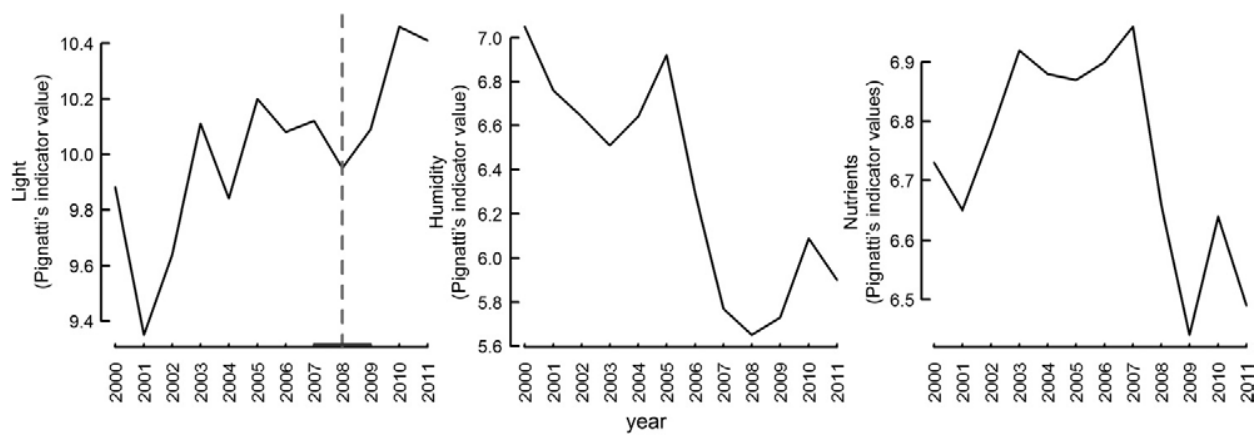

Fig. 6. Pignatti's bioindicator values (y axis) of aggregated plots of group b during succession ( $\mathrm{x}$ axis). Annual fluctuations can be observed, yet trends are also apparent. Vertical lines indicate the year during which a possible shift in both level and slope occurs. Horizontal lines around the year of possible shift indicate the period when t statistic of Zivot and Andrews test falls below the 0.05 level 


\section{Discussion}

Our results firstly demonstrate that the use of turnover rates estimated from equations 1 , 2 , and 3 cannot describe the succession patterns in 'Stergiou ecopark'. The consideration of only the presence/absence of taxa resulted in large inter-annual fluctuation of gains and losses of species which dominated the outputs. Conclusions cannot be drawn if cover/abundance values are not used and succession patterns remain unrevealed.

The changes in Sørensen's dissimilarity index showed that during the first years of succession, dissimilarity rapidly increased, reaching a milestone at the succession age of 7 and 9 years for groups a and b respectively (Fig. 4). Patterns of succession indicating a decline in rates with time have been widely discussed in the literature (FOSTER and TILMAN 2000) and are explained by the general succession mechanism as described in MYSTER and PICKETT (1994). It is argued that on abandoned agricultural fields, species gain increases with time, while species loss decreases, resulting in a decelerating decrease in overall species turnover (ANDERSON 2007), yet in the present study, dissimilarity is not due to gain or loss of species, as these patterns rather reflect random fluctuations (Fig. 3), and it should mostly be attributed to changes in species cover/abundance values resulting in changes in dissimilarity index. Cluster analysis, right from the first years of succession, identified rather pure clusters, consisting of the same plots each and there were only a few 'exchanges' observed, mainly between plots 3 and 4 at early and late stages of succession.

It has to be pointed out, though, that succession rates are different in the plots of group a and b. In the former group, differences in both dissimilarity and Pignatti's values are pronounced, reflecting a clear gradient of vegetation evolution. Dissimilarity between the first and the last examined year increases up to 0.8, while weight-averaged bioindicator values show a difference of up to one unit, indicating a shift in class as defined in PIGNATTI (2005). Plots of group b do not reflect such pronounced differences either in dissimilarity or in changes in Pignatti's values, although the identified trends in group $b$ are also significant. This indicates that plots of group b, from the very first year of succession, are 'stabilised' and their floristic composition does not radically change along the time trajectory.

Changes in taxa cover/abundance values in the study area are controlled, rather, by soil salinity and canopy cover. The presence of Salicornia europaea, Sarcocornia perennis, Hordeum marinum and Tamarix hampeana in the plots of the group b, indicate higher salt concentrations in these plots. Since irrigation has stopped, soil salinity is expected to increase and these salt-tolerant taxa quickly replaced other ruderal, salt-intolerant taxa and finally became dominant. High soil salinity in plots of group b restricts the potential rates of change through restricting the potential pool of species capable of establishing themselves after land abandonment. Salt tolerant taxa dominate the plotsright from the first years of succession, forming plant communities that remain quite stable over the years. Similar results were reported by MESLÉARD et al. (1991). In such special environments, the distinct abiotic conditions control the patterns of vegetation succession (ANDERSON 2007).

In contrast, plots of group a, due to their proximity to the bank of the Aliakmon, allowed Populus alba and Salix spp. to become established, most likely due to the high fresh-water table which is easily available to plant roots (MESLÉARD et al. 1991). These differences in the floristic composition of the defined groups can also indirectly demonstrate the effect of the distance to the river in succession trajectories. Certainly, reliable conclusions cannot be 
drawn from only two plots, but similar results, which support our argumentation, can be found in MESLÉARD et al. (1991), where forest canopy was only found to develop in the vicinity of rivers and irrigation canals. Differences in succession trajectories along salinity gradients have been reported previously (CRAIN et al. 2008), succession speed being negatively associated with an increasing salinity gradient.

Species turnover was also found to be higher during the first years of succession in ODLAND and DEL MORAL (2001) with stabilising indications after the $8^{\text {th }}-9^{\text {th }}$ year. Species diversity resembled the respective diversity of adjacent vegetation types five years after the beginning of succession but the colonisation from perennial species like Puccinellia maritima and Halimione portulacoides increased after the third year in an estuary under restoration in southern England (WOLTERS et al. 2008). A longer time series, a prerequisite for robust time series analysis, would allow us better to examine and reliably to conclude whether the indications of abrupt shifts are part of a constant trend in the succession or whether they are true shifts that indicate radical changes in succession rates. Fluctuations in environmental conditions may further result in fluctuations in species cover/abundance values that co-occur with directional changes (ODLAND and DEL MORAL 2001), and that could impede their discrimination.

Pignatti's bioindicator values revealed distinct succession patterns between groups a and b. Group a not only started from lower values for light (7.5 against 9.8) but unlike in group $\mathrm{b}$, these values rapidly decreased with a magnitude of 1.65 units in Pignatti's scale for light, indicating a shift toward classes of intermediate shade tolerance. This decrease is directly connected to the increasing density of shrub, during the early years, and tree canopy during the later years. Populus alba and Salix spp. (only the first years) rapidly colonised plots 1 and 2 and formed a dense canopy, forcing light demanding early-successional species to reduce their cover and abundance values until their reduction or extinction from the plots. Striking examples are the taxa Polypogon monspeliensis, Centaurium erythraea, Epilobium tetragonum, Conyza canadensis. In contrast, for group b (plots 3, 4, 5), where the canopy has not closed up to date, light-demanding species were favoured. The effect of stand closure in succession had been previously discussed and it is apparent in various ecosystems of the world, as for example pine plantations (JoNES et al. 2012).

The abrupt shift of moisture bioindicator values of plots of group a (Fig. 5), which is observed during the year 2005 (6 years after land abandonment) indicates a shift of floristic composition from moisture-demanding towards more water-stress tolerant taxa. This can be attributed to the high rates of moisture consumption from the poplars that exhaust the available soil moisture, reflecting rapid growth rates and biomass build-up from May up to June, depending on soil water availability (LIANG et al. 2006). Moreover, the lack of irrigation following land abandonment could have also affected hydrological conditions. Plots of group $\mathrm{b}$ maintained higher bioindicator values of moisture availability, although these plots are exposed to direct solar radiation due to canopy absence. Nevertheless, a decrease was similarly observed during 2005.

Pignatti's bioindicator values for nutrient availability also decreased after the first years of succession for the plots of group a, by a magnitude of $c a$ one degree, revealing the possible lagged effect of fertilisation. Agricultural practices of rice cultivation included soil fertilisation and therefore, during the first years of succession more nutrient-demanding taxa were able to become established. Lack of fertilisation alongside the rapid growth of 
poplars rapidly exhausted soil nutrients resulting in the decrease of bioindicator values. In contrast, in plots of group b, increased soil salinity did not allow nutrient-demanding, fast-growing species to be established and bioindicator values only slightly fluctuated.

Based on our results, we can conclude that succession rates and patterns in the estuary of the Aliakmon are dominated by two ecological factors, which, although not measured, can be discussed on the basis of species composition. Fresh water availability, assumed by the proximity to the river, allows fast-growth Populus alba to develop a forest canopy that radically alters the shading environment which, in its turn, controls succession trajectories. Increased soil salinity, on the other hand, allows salt tolerant taxa to be quickly established, and defines species composition on these sites as early as the first years of succession. Changes in species cover/abundance values are rather restricted and succession follows slower rates.

There are serious limitations regarding the present study. The number of plots is small, yet, all vegetation types occurring within the study area were recorded and the plot size allowed for the complete inventory of the most dominant species in the study area. Ecological data could provide valuable information enabling reliable conclusions to be drawn concerning environmental control of succession trajectories. Bioindicator values cannot be used as independent variables for the development of models, yet they stand as good proxies for a generalised description of the dominant ecological conditions of a site. We can infer, therefore, that in spite of the drawbacks our results provide a valid generalisation of the succession processes for the 'Stergiou ecopark' and, combined with further data, could provide valuable insights to the processes of succession in estuarine ecosystems.

\section{Acknowledgements}

The authors would like to thank the editor and the two reviewers for their valuable comments that significantly improved the manuscript.

\section{References}

ANDERSON, K. J., 2007: Temporal patterns in rates of community change during succession. American Naturalist 169, 780-793. doi:10.1086/516653

Austin, M. P., 1977: Use of ordination and other multivariate descriptive methods to study succession. Vegetatio 35, 165-175. doi:10.1007/BF02097067

BAKKeR, J. P., OlfF, H., Willems, J. H., ZoBEl, M., 1996: Why do we need permanent plots in the study of long-term vegetation dynamics? Journal of Vegetation Science 7, 147-155. doi:10.2307/3236314

Bohn, U., Gollub, G., Hettwer, C., Zupancic, M., Puncer, I., SelišKar, A., 2000: Karte der natürlichen Vegetation Europas: Massstab 1: 2500 000. Bundesamt für Naturschutz, Münster-Hiltrup.

Bonet, A., 2004: Secondary succession of semi-arid Mediterranean old-fields in south-eastern Spain: insights for conservation and restoration of degraded lands. Journal of Arid Environments 56, 213-233. doi:10.1016/S0140-1963(03)00048-X

Braun-Blanquet, J., 1964: Pflanzensoziologie-Grundzüge der Vegetationskunde, 3. Springer Verlang. 
Brinson, M. M., MALvÁREZ, A. I., 2002: Temperate freshwater wetlands: types, status, and threats. Environmental Conservation 29, 115-133. doi:10.1017/S0376892902000085

Crain, C. M., Albertson, L. K., Bertness, M. D., 2008: Secondary succession dynamics in estuarine marshes across landscape-scale salinity gradients. Ecology 89, 2889-2899. doi:10.1890/07-1527.1

DiEKMANN, M., 2003: Species indicator values as an important tool in applied plant ecology - a review. Basic and Applied Ecology 4, 493-506. doi:10.1078/1439-1791-00185

Du, F., SHAO, H.-B., SHAN, L., LiAng, Z.-S., SHAO, M.-A., 2007: Secondary succession and its effects on soil moisture and nutrition in abandoned old-fields of hilly region of Loess Plateau, China. Colloids and Surfaces B: Biointerfaces 58, 278-285. doi:10.1016/j.colsurfb. 2007.04.002

Dzwonko, Z., 2001: Assessment of light and soil conditions in ancient and recent woodlands by Ellenberg indicator values. Journal of Applied Ecology 38, 942-951. doi:10. 1046/j.1365-2664.2001.00649.x

EuRO+MED 2006-2010 Euro+Med PlantBase - the information resource for Euro-Mediterranean plant diversity. Retrieved March 31, 2010 from http://ww2.bgbm.org/EuroPlus $\mathrm{Med} /$.

EWALD, J., 2003: The sensitivity of Ellenberg indicator values to the completeness of vegetation releves. Basic and Applied Ecology 4, 507-513. doi:10.1078/1439-1791-00155

FASTIE, C. L., 1995: Causes and ecosystem consequences of multiple pathways of primary succession at Glacier Bay, Alaska. Ecology 76, 1899-1916. doi:10.2307/1940722

Foster, B. L., Tilman, D., 2000: Dynamic and static views of succession: Testing the descriptive power of the chronosequence approach. Plant Ecology 146, 1-10. doi:10. 1023/a:1009895103017

Gerakis, A., Kalburtu, K., 1998: Agricultural activities affecting the functions and values of Ramsar wetland sites of Greece. Agriculture Ecosystems \& Environment 70, 119 128. doi:10.1016/S0167-8809(98)00119-4

Greuter, W., Burdet, H. M., Long, G., 1984, 1986, 1989: Med-checklist. A critical inventory of vascular plants of the circum-mediterranean countries, 1, 3, 4. Conservatoire et Jardin Botaniques, de la Ville de Genève, Genève.

Hipel, K. W., MCLEOD, A. I., 1994: Time series modelling of water resources and environmental systems. Elsevier, Amsterdam.

HobBs, R. J., WALKer, L. R., WALKer, S., 2007: Integrating restoration and succession. In: WALKER, L. R., WALKER, J., HobBS, R. J. (eds), Linking restoration and ecological succession. Springer Series on Environmnetal Management. Springer, New York.

JAHN, R., SCHÖNFELDER, P., 1995: Excursion Flora Für Kreta. Ulmer, Stuttgart

Jones, P. D., Demarais, S., Ezell, A. W., 2012: Successional trajectory of loblolly pine (Pinus taeda) plantations established using intensive management in Southern Mississippi, USA. Forest Ecology and Management 265, 116-123. doi:10.1016/j.foreco.2011.10.037

Kahmen, S., Poschlod, P., 2004: Plant functional trait responses to grassland succession over 25 years. Journal of Vegetation Science 15, 21-32. doi:10.1111/j.1654-1103.2004. tb02233.x

KöPPEN, W., 1931: Die Klimate der Erde. Walter de Gruyter, Berlin 
Laurence, M., Jones, M., Sowerby, A., Rhind, P., 2010: Factors affecting vegetation establishment and development in a sand dune chronosequence at Newborough Warren, North Wales Journal of Coastal Conservation 14, 127-137. doi:10.1007/s11104-0089601-9

LiANG, Z.-S., YANG, J.-W., SHAO, H.-B., HAN, R.-L., 2006: Investigation on water consumption characteristics and water use efficiency of poplar under soil water deficits on the Loess Plateau. Colloids and Surfaces B: Biointerfaces 53, 23-28. doi:10.1016/j.colsurfb. 2006.07.008

Matthews, J. W., Endress, A. G., 2010: Rate of succession in restored wetlands and the role of site context. Applied Vegetation Science 13, 346-355. doi:10.1111/j.1654-109X. 2010.01076.x

McCunE, B., MEFFord, M. J., 2006: PC-ORD. Multivariate analysis of ecological data. 5.33 edn. MjM Software, Oregon, U.S.A.

MesléARD, F., Grillas, P., LePART, J., 1991: Plant community succession in a coastal wetland after abandonment of cultivation - the example of the Rhone delta. Vegetatio 94, 35-45. doi:10.1007/BF00044914

Myster, R. W., Pickett, S. T. A., 1994: A comparison of the rate of succession over $18 \mathrm{yr}$ in 10 contrasting old fields. Ecology 75, 387-392. doi:10.2307/1939542

OdLAND, A., DEL Moral, R., 2001: Thirteen years of wetland vegetation succession following a permanent drawdown. Plant Ecology 162, 185-198. doi:10.1023/A:1020388910724

PignATTI, S., 2005: Valori di bioindicazione delle piante vascolari della flora d'Italia Braun-Blanquetia 39, 97.

Prach, K., Bartha, S., Joyce, C. B., Pysek, P., van Diggelen, R., Wiegleb, G., 2001: The role of spontaneous vegetation succession in ecosystem restoration: A perspective. Applied Vegetation Science 4, 111-114. doi:10.1111/j.1654-109X.2001.tb00241.x

PRACH, K., WALKER, L. R., 2011: Four opportunities for studies of ecological succession. Trends in Ecology and Evolution 26, 119-123. doi:10.1016/j.tree.2010.12.007

Prévosto, B., Kuiters, L., Bernhardt-Römermann, M., Dolle, M., Schmidt, W., Hoffmann, M., van Uytvanck, J., Bohner, A., Kreiner, D., Stadler, J., KlotZ, S., Brandl, R., 2011: Impacts of land abandonment on vegetation: successional pathways in European habitats. Folia Geobotanica 46, 303-325. doi:10.1007/s12224-010-9096-Z

R Development Core Team, 2011: R, A Language and Environment for Statistical Computing. 2.14.0 edn., Vienna, Austria

ŘehounkovÁ, K., PrACH, K., 2008: Spontaneous vegetation succession in gravel-sand pits: A potential for restoration. Restoration Ecology 16, 305-312. doi:10.1111/j.1526-100X. 2007.00316.x

Roozen, A. J. M., Westhoff, V., 1985: A study on long-term salt-marsh succession using permanent plots. Vegetatio 61, 23-32. doi:10.1007/BF00039807

Rossell, I. M., Moorhead, K. K., Alvarado, H., Warren, R. J., 2009: Succession of a Southern Appalachian Mountain Wetland Six Years following Hydrologic and Microtopographic Restoration. Restoration Ecology 17, 205-214. doi:10.1111/j.1526-100X. 2008.00372.x

SMARDON, R. C., 2009: Sustaining the world's wetlands - setting policy and resolving conflicts. Springer, New York. doi:10.1007/978-0-387-49429-6_3 
SMART, S. M., SCOTT, W. A., 2004: Bias in Ellenberg indicator values-problems with detection of the effect of vegetation type. Journal of Vegetation Science 15, 843-846. doi:10. 1111/j.1654-1103.2004.tb02327.x

StrID, A., TAN, K., 1997: Flora Hellenica, I. Koeltz Scientific Books, Königstein

StrID, A., TAN, K., 2002: Flora Hellenica, II. A. R. G. Gartner. Verlag. K.G. Ruggell,

Tropek, R., Kadlec, T., Karesova, P., Spitzer, L., Kocarek, P., Malenovsky, I., Banar, P., Tuf, I. H., HeJdA, M., KonvickA, M., 2010: Spontaneous succession in limestone quarries as an effective restoration tool for endangered arthropods and plants. Journal of Applied Ecology 47, 139-147. doi:10.1111/j.1365-2664.2009.01746.x

Tutin, T. G., Burges, N. A., Charter, A. O., Edmondson, J. R., Heywood, V. H., Moore, D. M., Valentine, D. H., Walters, S. M., WebB, D. A. E., 1993: Flora Europaea I. Cambridge University Press, Cambridge

Tutin, T. G., Heywood, V. H., Burges, N. A., Moore, D. M., Valentine, D. H., Walters, S. M., WebB, D. A. E., 1968: Flora Europaea II. Cambridge University Press, Cambridge.

Tutin, T. G., Heywood, V. H., Burges, N. A., Moore, D. M., Valentine, D. H., Walters, S. M., WebB, D. A. E., 1972: Flora Europaea III. Cambridge University Press, Cambridge.

Tutin, T. G., Heywood, V. H., Burges, N. A., Moore, D. M., Valentine, D. H., Walters, S. M., WeBB, D. A. E., 1976: Flora Europaea IV. Cambridge University Press, Cambridge.

Tutin, T. G., Heywood, V. H., Burges, N. A., Moore, D. M., Valentine, D. H., Walters, S. M., WebB, D. A. E. 1980: Flora Europaea V. Cambridge University Press, Cambridge.

VAN DER MAAREL, E., 2007: Transformation of cover-abundance values for appropriate numerical treatment - Alternatives to the proposals by Podani. Journal of Vegetation Science 18, 767-770. doi:10.1111/j.1654-1103.2007.tb02592.x

Wolters, M., Garbutt, A., Bekker, R. M., Bakker, J. P., CArey, P. D., 2008: Restoration of salt-marsh vegetation in relation to site suitability, species pool and dispersal traits. Journal of Applied Ecology 45, 904-912. doi:10.1111/j.1365-2664.2008.01453.x

Xystrakis, F., Eleftheriadou, E., Theodoropoulos, K., Damianidis, C., Samaras, D., PAPAdOPOUlOS, T., 2011: Secondary succession patterns in a deltaic ecosystem in N. Greece (in Greek). Proceedings 15 Panhellenic Forestry Conference, Karditsa, Greece, 803-814.

Zalidis, G., Mantzavelas, A., Gourvelou, E., 1997: Environmental impacts on Greek wetlands. Wetlands 17, 339-345. doi:10.1007/bf03161423

ZeDLER, J. 2005: Ecological restoration: guidance from theory. San Francisco Estuary and Watershed Science 3, 1-31. 